\title{
The Effect of Injection Parameters on Fuel Consumption and Emissions in A PFI Small Spark Ignition Engine
}

\author{
Abdurrahman Demirci ${ }^{1}$, Hüseyin Emre Doğan², Ömer Cihan ${ }^{3 *}$, Osman Akın Kutlar ${ }^{4}$ \\ 0000-0002-2569-5174, 0000-0002-9445-3697, 0000-0001-8103-3063, 0000-0002-4795-3541
}

${ }^{1}$ Karamanoğlu Mehmetbey University, Mechanical Engineering Department, Karaman, 70200, Turkey.

${ }^{2}$ Karamanoğlu Mehmetbey University, Mechanical Engineering Department, Karaman, 70200, Turkey.

${ }^{3}$ Hakkari University, Mechanical Engineering Department, Hakkari, 30000, Turkey.

${ }^{4}$ Istanbul Technical University, Mechanical Engineering Department, Istanbul, 34469, Turkey.

\section{Abstract}

Mixture formation in port fuel spark ignition engines is one of the most important parameters, which affect combustion and emissions. In this study, the effects of different injection start timings and some other port fuel injection (PFI) parameters on the performance and emissions of a water cooled and single cylinder spark ignition engine were examined experimentally. The experiments were performed at different engine speeds (1200 and $1500 \mathrm{rpm}$ for effect of injection pressure and $1500 \mathrm{rpm}$ for changing injection timings) and different engine loads ( 3 bar and 5 bar for injection pressure and 1 bar and 5 bar for start of injection). The start of injection was chosen according to intake pressure measurements. The experiment results showed that brake specific fuel consumption (BSFC) and total hydrocarbon (THC) emissions are increased by the increase of the injection pressure. Because with the increase of injection pressure, the fuel can reach the intake manifold wall or intake valve. Therefore, the fuel enters the cylinder as a droplet. Different start of injection experiments showed that injection times have an effect on emissions and performance. The minimum brake specific fuel consumption and THC values were obtained at $-243{ }^{\circ} \mathrm{CA}$ value of injection start. The twice injection in one cycle increased brake specific fuel consumption and THC emissions.

Keywords: Spark ignition engine, Start of injection, Injection pressure, Brake specific fuel consumption, THC emissions

\section{Research Article}

https://doi.org/10.30939/ijastech..910542

$\begin{array}{ll}\text { Received } & 06.04 .2021 \\ \text { Revised } & 25.04 .2021 \\ \text { Accepted } & 26.04 .2021\end{array}$

* Corresponding author

Ömer Cihan

omercihan@hakkari.edu.tr

Address: Hakkari University, Mechanical Engineering Department, Hakkari, 30000, Turkey.

Tel:+903122028653

\section{Introduction}

The fastening of emission standards and the desire to lower fuel consumption decide the direction of research on internal combustion engines. Mixture formation affects fuel consumption and harmful emissions. One of the common problems in spark-ignition engines with liquid fuels is the evaporation of fuel for mixing with air because of fuel stored in liquid form. The intake valve is hot in port fuel injection engines. The fuel is directed to the hot surface of the intake valve so it evaporates. The injection pressure, injection time, injection angle and the number of injections in one cycle affect mixture formation [1-7].

The effect of different injectors and injection methods were investigated by Kim et al. $\mathrm{HC}$ emissions were reduced when the fuel injected behind of intake valve with smaller droplet size. Open valve injection forms higher $\mathrm{HC}$ emissions than close valve injection in cold start. The fuel droplets cannot evaporate in the first cycle of engine start-up because of the cold intake manifold. Mixture formation gets better when turbulence is created in the intake manifold [8].

Meyer et al. investigated the fuel film formed in the intake port of spark ignition engines. The close valve injection forms a thick fuel film in the intake port after the first cold running of the engine for fifteen seconds. As the engine runs, the film thickness decreases because of the hot intake valve and port. The droplet diameter is changed by increasing port temperature [9].

The injection system must provide excellent atomization of the fuel for the lowest releasing amount of $\mathrm{HC}$ emissions. When the fuel is injected behind of intake valve, the wetness on the intake port is decreased $[10,11]$. 
Anand et al examined the importance of injection time and location. When the injector angle and position are not adjusted properly, fuel film is formed on the intake port and valve. The less $\mathrm{HC}$ emission is obtained when fuel is injected behind of injection valve in open valve injection [12].

Port Fuel Injection (PFI) system is widely used in gasoline engines. A PFI injector generally operates at pressures between 3 bar and 5 bar and its operating temperature rises to $80^{\circ} \mathrm{C}$. Therefore, they are significantly cheaper to produce [13]. A regular PFI injector produces droplets with Sauter mean diameter between 70 and $150 \mu \mathrm{m}$. If the fuel droplets are too large, they can crash the port walls, and thus the mixture formation becomes less dependent on the droplet size [14]. Moreover, more dependent upon the fuel film transient behavior. Open valve injection produced smaller mean diameters as fuel passed through the valve gap. Kato et al. [15] conducted in an experimental and numerical study, their showed that cyclical variations in combustion affect the formation of the mixture in the combustion chamber and around the spark plug. Arcoumanis et al. [16] investigated droplet velocity/size and mixture distribution in a single-cylinder spark-ignition engine. Laser Doppler velocimetry, phase Doppler anemometry, and Mie scattering were carried out for transparent liner and piston. Research has been done on lean air/fuel mixture ratios of 17.5 and 24, tumble flow droplet size and velocity distributions during intake and compression stroke. Pressure analysis was carried out thanks to the mixture distribution and flame images obtained with two injection strategies. As a result, it is advantageous to combine open valve injection with a tumble, engine operating more stable and efficient and faster flame growth at 24 air / fuel ratio. Lang and Cheng [17] focused on the extent to which the interaction of the intake port gas flow within a port-fuel-injection engine facilitates the mixture preparation process, and whether there is improvement in $\mathrm{HC}$ emissions through this interaction. The result was a slight improvement (compared to closed valve injection) in cold valve conditions, with a second pulse of fuel $25 \%$ : a $6 \%$ reduction in specific $\mathrm{HC}$ emissions and a $4.5 \%$ increase in the fuel delivery fraction. Hushim et al. [18] investigated the effects of the intake manifold angle of a PFI retrofit kit on engine performance and emission characteristics. In the experimental study, the engine was operated on a wide open throttle with variable dynamometer loads for two different angles, $90^{\circ}$ and $150^{\circ}$. The angle of $150^{\circ}$ was found to be the optimum angle for brake power (BP) and brake mean effective pressure (BMEP), brake specific fuel consumption (BSFC) and hydrocarbon (HC) emission parameters.

From the literature review, the effect of injection parameters of PFI gasoline spark ignition engine on performance and emissions has not been clearly researched. Therefore, more studies should be done to get more information about the deficiencies of these topics in the literature. Because of that, the aim of this study is the investigation of injection start angle, injection pressure and injection number per cycle on engine parameters and its emissions.

\section{Experimental Study}

Experiments were made in the engine laboratory of Istanbul
Technical University. They were made with a single cylinder research engine, which was originally a four stroke compressed ignition Antor 3LD 450 engine. Further details about the engine are given in Table 1. The engine was converted to a spark ignition engine by adding a throttle valve and electronic control unit (ECU) [19]. The Spark plug was relocated to the injector location. Spark plug location is nearly the center of the piston head. ECU, designed and manufactured as a part of a master thesis, controls the start of injection, duration and ignition period. The hardware card used in ECU is an Ardunio Mega 2560. Fuel injection pressure and timing were able to change. Dwell duration was set to $5 \mathrm{~ms}$ for ignition [20]. The maximum original engine power and torque are $10 \mathrm{HP}$ at $3000 \mathrm{rpm}$ and $30 \mathrm{Nm}$ at $1800 \mathrm{rpm}$ respectively. The injector used in the experiments is Bosch EV 6.2 L. It has four holes for the injection of gasoline fuel. The injection angle is 25 degrees at a 300 $\mathrm{kPa}$ pressure. The fuel injection pressure could be changed according to the desired value with the fuel supply system. The start of injection was changed with an electronic control unit.

Table 1. Detailed information about engine.

\begin{tabular}{c|c}
\hline Engine Model & Antor 3LD 450 \\
\hline Compression Ratio & $10.5: 1$ \\
\hline Number of Cylinders & 1 \\
\hline Fuel type & Gasoline \\
\hline Displacement & $454 \mathrm{~cm}^{3}$ \\
\hline Bore & $85 \mathrm{~mm}$ \\
\hline Stroke & $80 \mathrm{~mm}$ \\
\hline Connection Rod Length & $145 \mathrm{~mm}$ \\
\hline Power & $7.35 \mathrm{~kW}(3000 \mathrm{rpm})$ \\
\hline Torque & $28.5 \mathrm{Nm}(1700 \mathrm{rpm})$ \\
\hline Emission tier & EU Stage II
\end{tabular}

Fig. 1 shows the experimental apparatus. The engine was loaded by an eddy current dynamometer. The load on the dynamometer was measured by using a strain gauge load sensor. The accuracy of the load sensor is $\pm 0.02 \%$. An inductive pickup speed sensor was used to measure the speed of the engine. The accuracy of the speed sensor is $\pm 3 \mathrm{rpm}$. Fuel consumption was measured with AVL 733S fuel consumption measurement and conditioning system. The accuracy of the fuel measurement system is $\pm 0.08 \mathrm{~kg} / \mathrm{h}$. The exhaust emissions, $\mathrm{CO}_{2}, \mathrm{THC}$, and $\mathrm{CO}$ were sampled directly from the exhaust pipe. Emission concentrations and excess air coefficient were measured and calculated by exhaust gas analyzers (Horiba Mexa 7500).

A laboratory automation system produced by OTAM. This system collected all data, such as exhaust gas, lubricating oil and other temperatures, the position of the throttle valve, intake and exhaust pressure from sensors. During the test, the temperature of the cooling water was kept constant at around 72 degrees Celsius. The experimental data were recorded for 90 seconds using an automation system. Ignition advance for maximum torque (MBT) is obtained at each experimental point. The excess air coefficient $(\lambda)$ was set to 1 (stoichiometric mixture) for all experiments. The intake manifold temperatures were about $44^{\circ} \mathrm{C}$ and $37^{\circ} \mathrm{C}$ for 1 and 5 bar of 
MEP at 1200 rpm engine speed respectively. At $1500 \mathrm{rpm}$ engine speed, the values of air inlet temperature were respectively 42,41 ,

and $35^{\circ} \mathrm{C}$ at 1,3 , and 5 bar engine load.

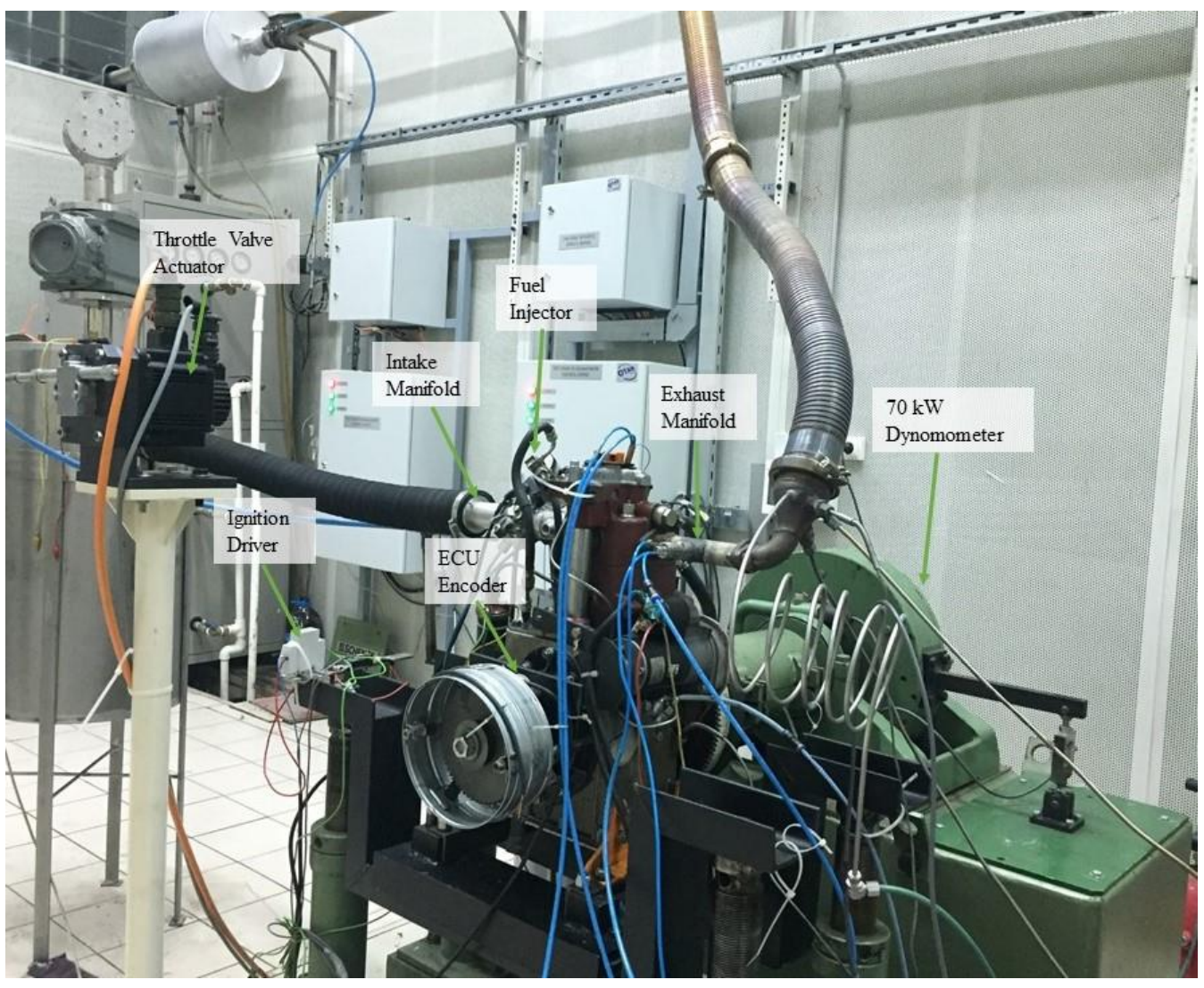

Fig. 1. Antor 3LD 450 single cylinder research engine.

\section{Results and Discussions}

The BSFC, THC and CO values are shown in Fig. 2 for different injection numbers in one cycle at 1200 and $1500 \mathrm{rpm}$ speeds. Different injection numbers in one cycle were occurred according to the connection situation of the encoder to the crankshaft or camshaft.

The once injection is called as a cam and twice injection is called a crank in figures. When the encoder is coupled to the camshaft the once injection is obtained. Twice injection occurs when the encoder is connected to the crankshaft. The injection was performed when the intake valve was opened in one injection. In twice, injections were performed in intake and expansion times. The BSFC and THC values are less for once injection at all speeds and loads. Since there is airflow at the moment of injection in the intake manifold, the fuel is carried by air and does not reach the wall in one injection. In twice injection, there is no airflow in the expansion stroke. So fuel can reach the manifold wall and enters the cylinder as droplets. The fuel entered in the liquid phase increases THC emission and BSFC value. CO emission mostly depends on excess air coefficient. It was changed with little uncontrolled differences of excess air coefficient values.
The BSFC, THC and CO values are depicted in Fig. 3 for different injection pressures (1, 2 and 4 bar) at different loads (1, 3 and 5 bar value of MEP) and $1500 \mathrm{rpm}$ constant engine speed. The fuel was injected one time for all injection pressure experiments. When the fuel was injected at 4 bar the engine load was not able to be obtained less than the 1.20 bar value of MEP. So the BSFC value of 4 bar injection less than others at 1 bar load. With the increase of injection pressure, fuel reaches the intake manifold wall and fuel enters the cylinder in liquid form. The values of BSFC and THC increased with the rising of injection pressure at higher loads. $\mathrm{CO}$ emission values changed according to excess air coefficient. It was able to be obtained less or more for different injection pressures at different loads.

The Electronic control unit (ECU) set different injection start angles. Fig. 4 shows injection start angles (-343, -243, -143, 150 and $250^{\circ} \mathrm{CA}$ ) according to crank angle (CA) values. The injections were made at intake and exhaust periods. The intake valve is opened on intake and closed on the exhaust period. The experiment points were chosen roughly at the start, mean and end of the intake period. It is the same for the exhaust period of start and mean. The spark advance was set to the same value all injection starts at the same loads. 

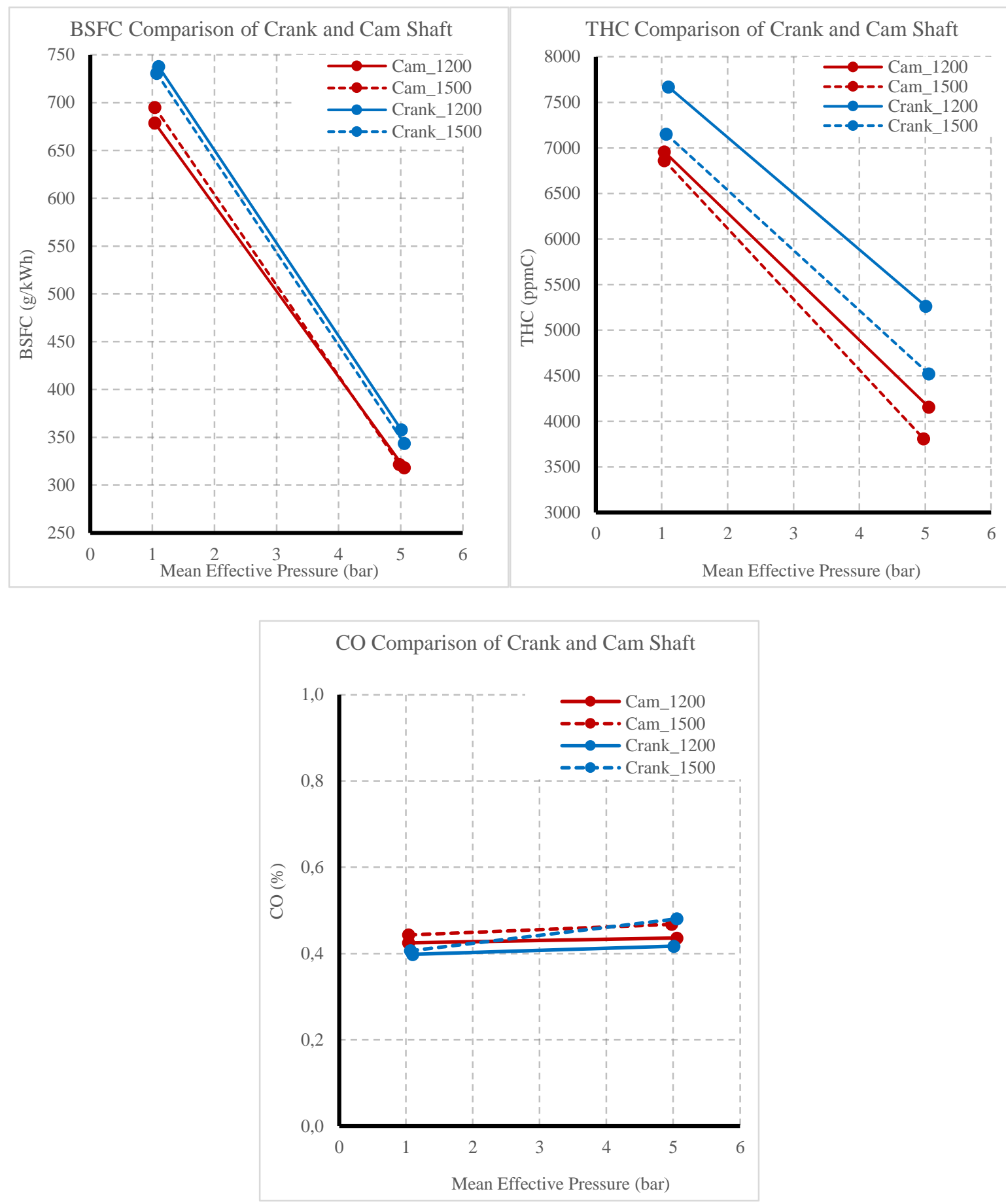

Fig. 2. BSFC, THC and $\mathrm{CO}$ emissions for different injection numbers in one cycle. 


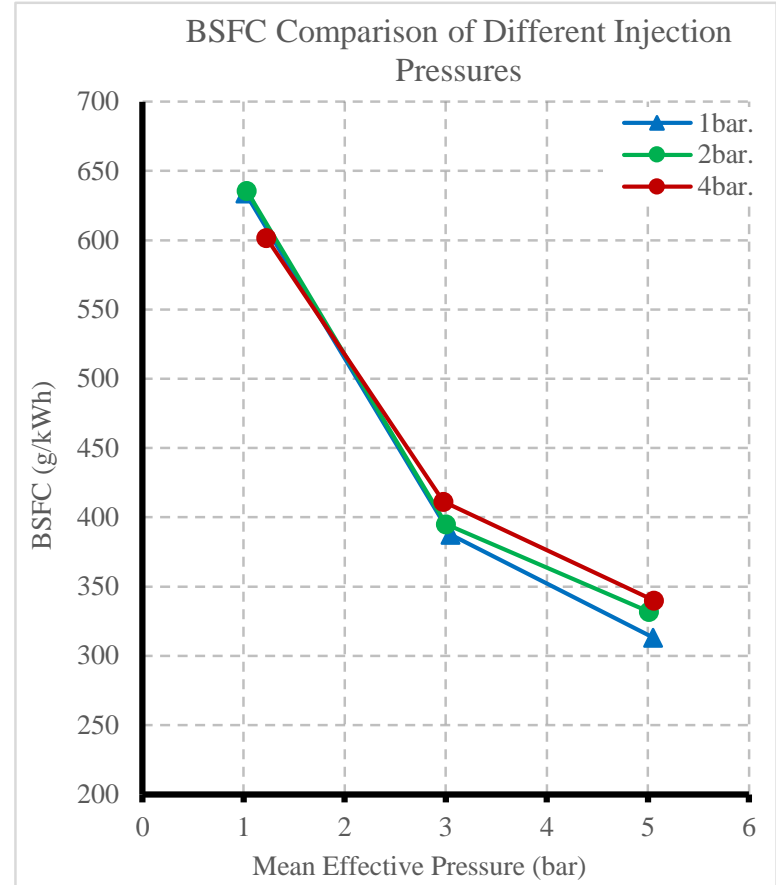

THC Comparison of Different Injection Pressures

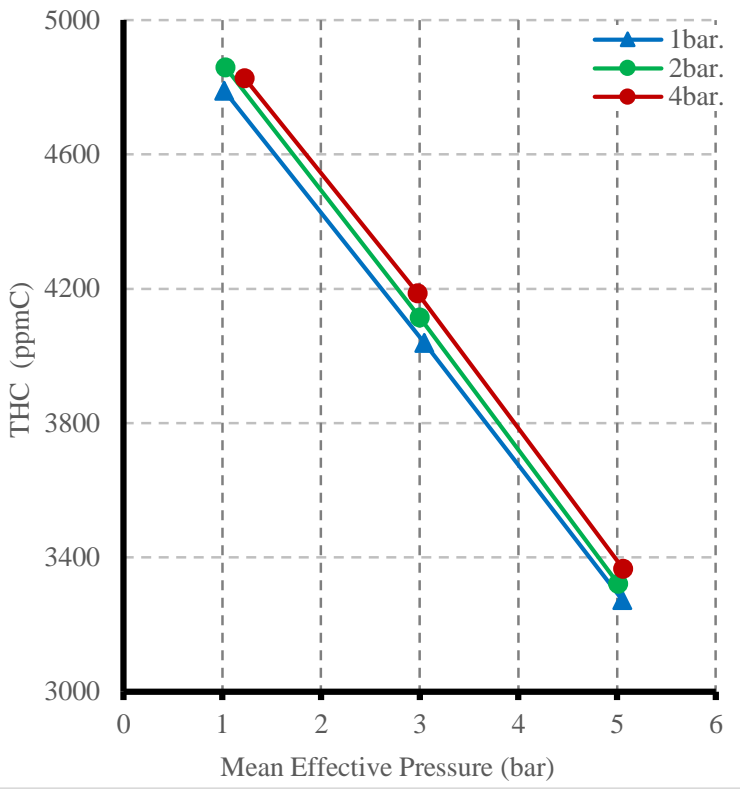

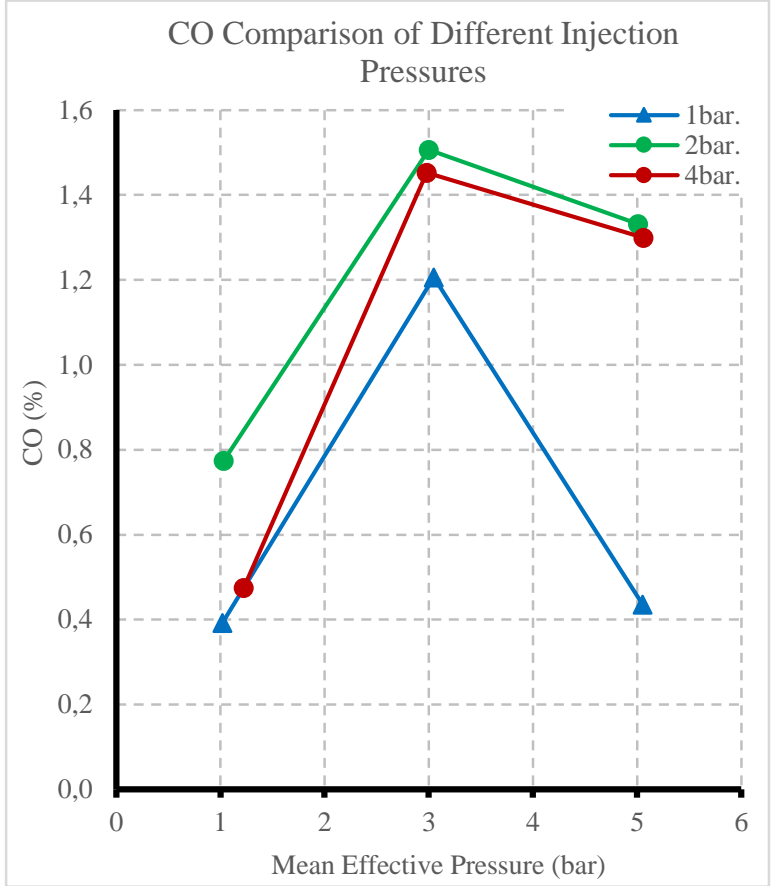

Fig. 3. BSFC, THC and CO emissions for different injection pressures at different loads and 1500 rpm constant speed. 


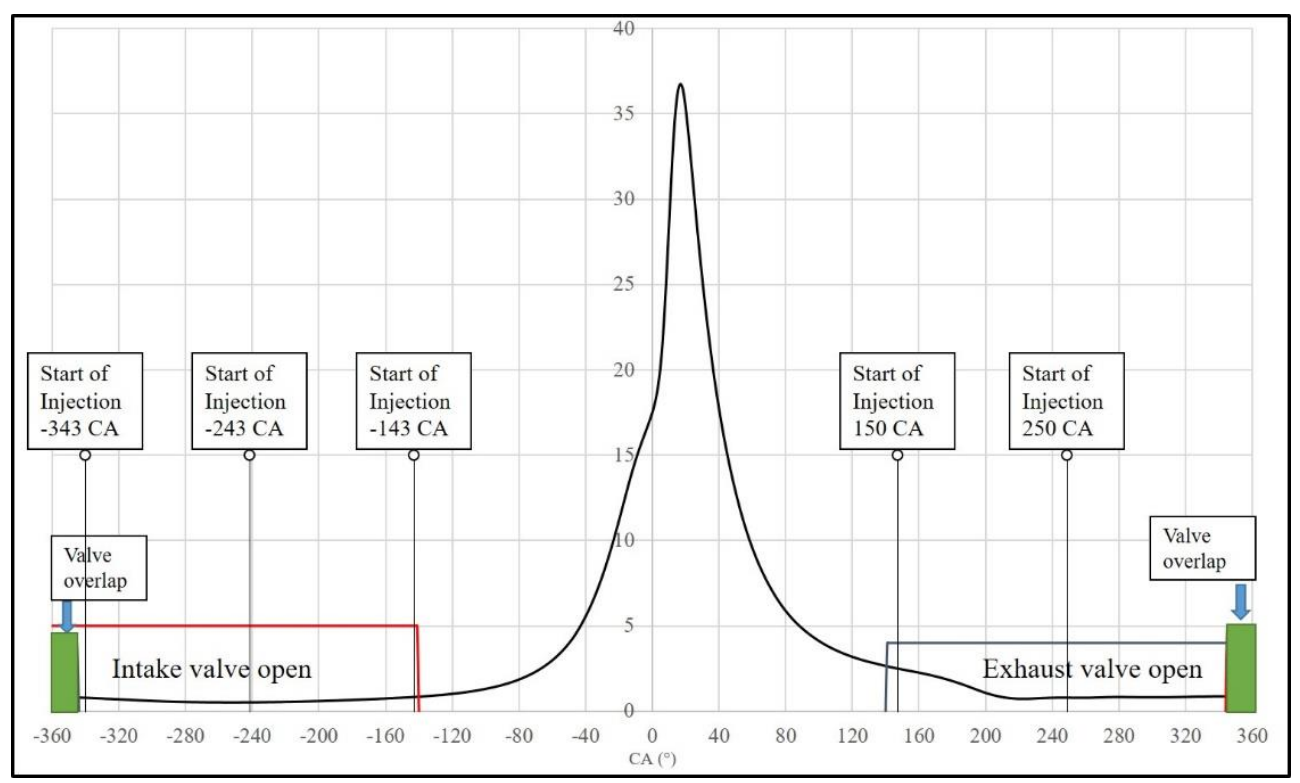

Fig. 4. Injection start angles.

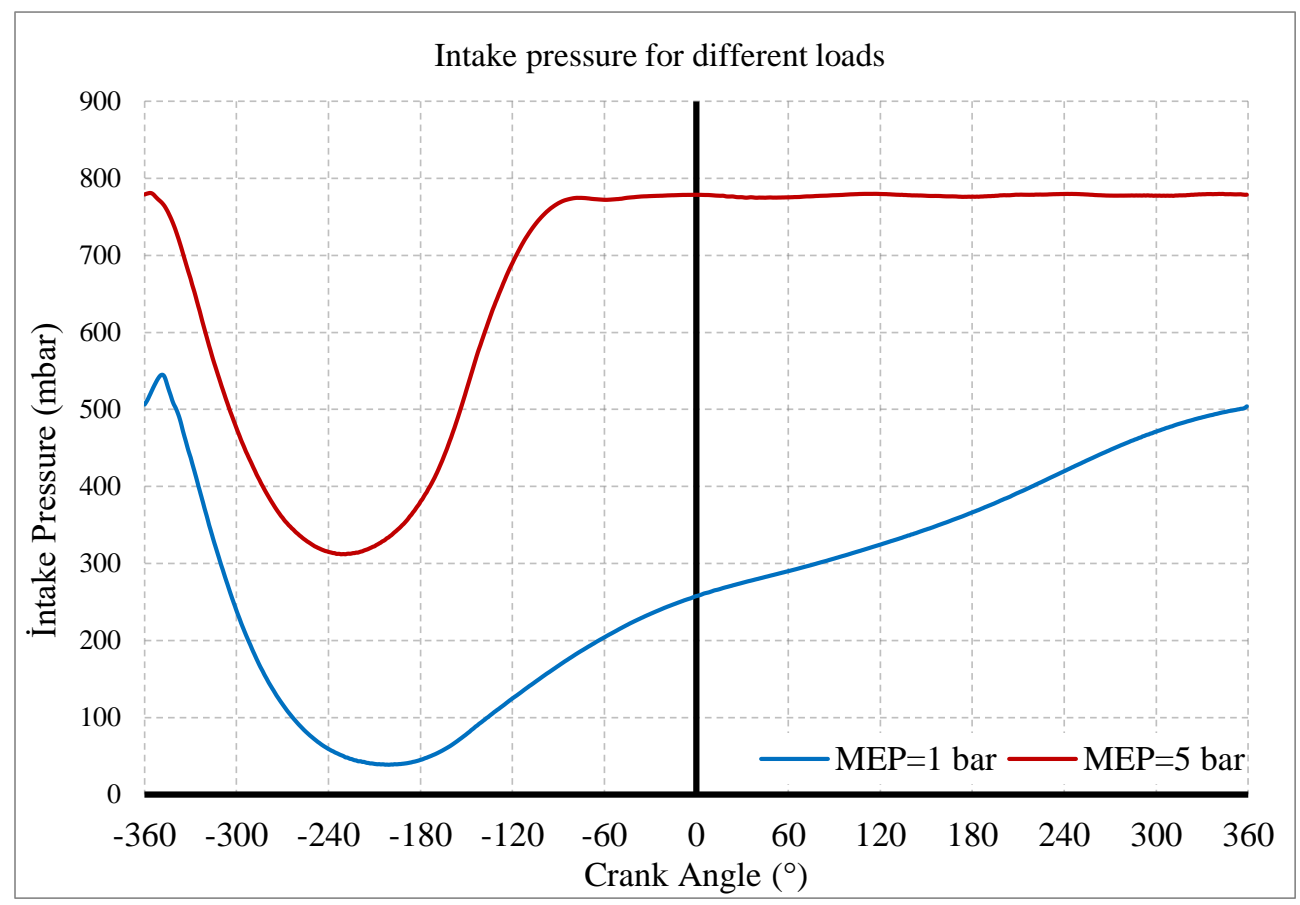

Fig. 5. Intake pressure values for different loads.

The act of fuel in the intake port, when injected in liquid form, depends on many parameters like temperature and pressure. One of the most critical parameters for comparing of entering fuel into the cylinder is the injection start angle. The fuel can be injected while airflow is present or absent. If Air flows, it can carry fuel to the cylinder. Fuel can reach the manifold wall without airflow. Besides that, the temperature of the intake manifold affects the situation of fuel too. High temperatures evaporates liquid fuel $[21,22]$.
Intake manifold pressures for 1 and 5 bar values of MEP are depicted in Fig. 5. The lowest values of intake manifold pressure were obtained around $(-260)-(-180)$ crank angle $\left({ }^{\circ} \mathrm{CA}\right)$ in the intake stroke. Therefore, injection in the regions at the lowest manifold pressure generated positive results for the formation of the mixture. There is no airflow when the intake valve is closed. The intake manifold temperature rises with decreasing of the load.

The change of BSFC, THC and CO is given in Fig. 6 for different injection start angles $\left(-343,-243,-143,150\right.$ and $\left.250{ }^{\circ} \mathrm{CA}\right)$ at 1 
and 5 bar value of MEP and $1500 \mathrm{rpm}$ constant engine speed. The intake manifold pressure is lower for one bar value of MEP. There is less airflow in the intake manifold because of the throttle valve position. Since fuel, can reach the wall and enter cylinders as a droplet. Fuel evaporates better than low loads. The BSFC and THC values are less for high load at higher loads ( 5 bar value of MEP). At high load, there is more airflow and higher intake manifold temperature. As a result, increasing of the load decreases BSFC and THC values. CO does not depend on the load. It strongly depends on the excess air coefficient. The effect of injection start angle varies with the airflow and intake manifold pressure. Air can carry fuel to the cylinder if the intake valve is open and air flows into the cylinder. The lowest BSFC and THC values are obtained for the $243{ }^{\circ} \mathrm{CA}$ value of start injection. Because fuel mixed better with air due to airflow. The BSFC and THC values are higher for $343{ }^{\circ} \mathrm{CA}$ of injection start. Because there is not more airflow and fuel can reach the intake valve and can enter as a droplet. The other starts were performed in the close situation of the intake valve. Because of that fuel can reach the intake manifold and enter the cylinder as a droplet. CO changed independently of start CA of injection.
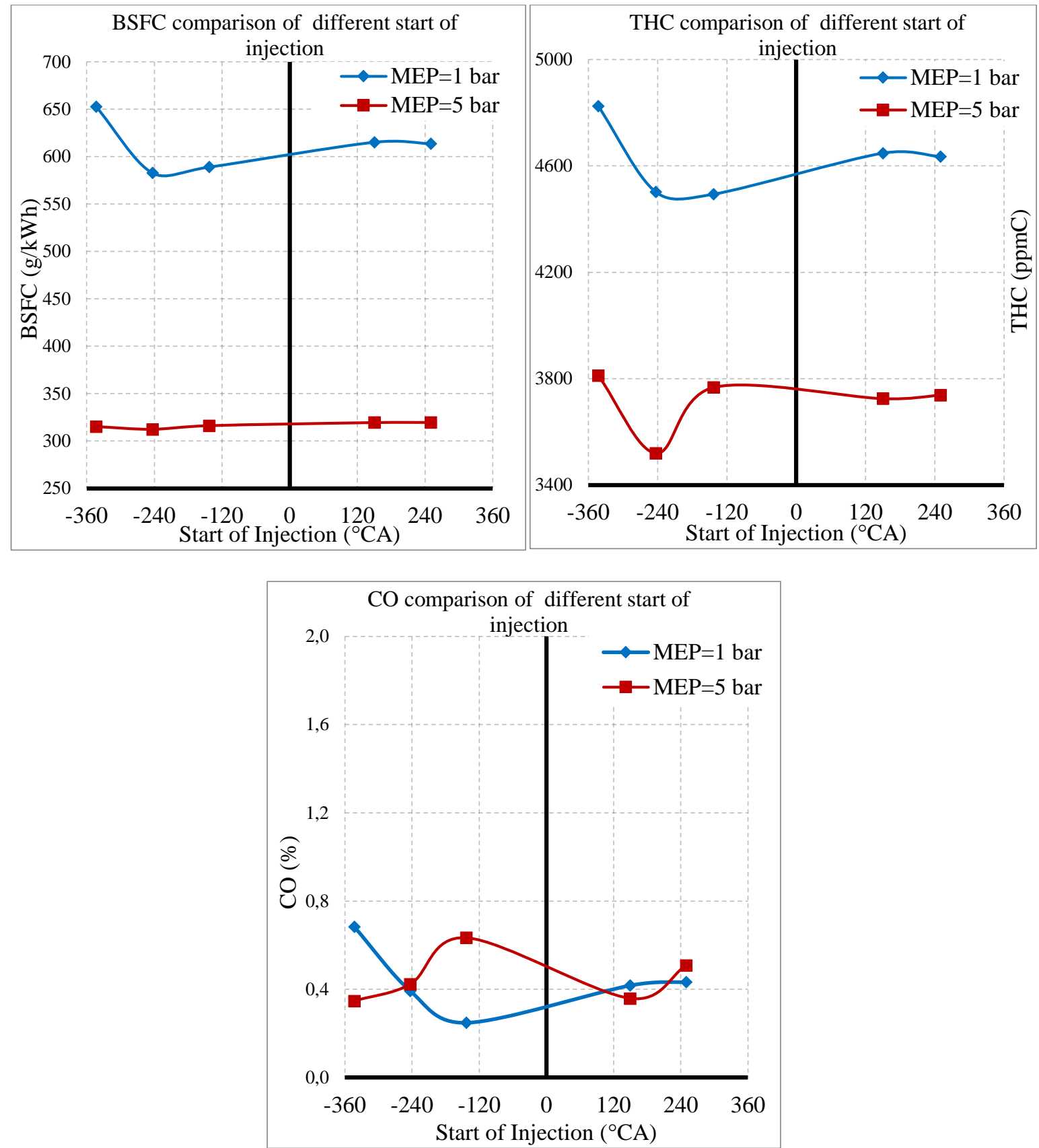

Fig. 6: THC and CO emissions for different injection starts at different loads and $1500 \mathrm{rpm}$ constant engine speed. 


\section{Conclusion}

The results of experiments showed that the connecting of the encoder to the camshaft decreases brake specific fuel consumption and THC emission.

- When the encoder was mounted to the camshaft (one injection per a cycle), the BSFC value was reduced by about $9.5 \%$ and $5 \%$ at 1200 and $1500 \mathrm{rpm}$ engine speeds, respectively.

- At this running situation, THC emission was reduced about $10 \%$ at all loads and speeds.

- The rising injection pressure increased BSFC and THC value.

- The changing of injection pressure from 4 bar to 1 bar decreased BSFC and THC emission by about $7 \%$ and $3.5 \%$ respectively at higher than one bar load and at all engine speeds.

- At low engine load (1 bar value of MEP), the start angle of injection strongly affects BSFC and THC values. $243{ }^{\circ} \mathrm{CA}$ value of injection start decreases roughly by $5 \%$ these parameters.

- At 5 bar load, injection start do not affect strongly BSFC and THC value. Because intake manifold temperature is higher than lower load. As a result of that, it evaporates more liquid fuel. The lowest values of BSFC and THC were found for $-243{ }^{\circ} \mathrm{CA}$ injection start at 5 bar load like 1 bar.

- The CO emission strongly depends on the excess air coefficient. The change of injection situations like different injectors did not affect this emission value.

As a recommendation for future studies, the researchers can study the footprints of liquid fuel on the intake manifold and intake valve. Besides that, the test engine can be run at higher loads and higher engine speeds for getting more knowledge about these running conditions.

\section{Acknowledgment}

The Authors thank the supporter of this project Istanbul Technical University Scientific Research Project Unit, Turkey Bosch auto parts, OTAM and team of automotive laboratory.

\section{Nomenclature}

$\begin{array}{ll}B M E P & : \text { Brake Mean Effective Pressure } \\ B P & : \text { Brake Power } \\ B S F C & : \text { Brake Specific Fuel Consumption } \\ C A & : \text { Crank Angle } \\ C O & : \text { Carbon Monoxide } \\ E C U & : \text { Electronic Control Unit } \\ H C & : \text { Hydrocarbon } \\ H P & : \text { Horse Power } \\ M E P & : \text { Mean Effective Pressure } \\ M B T & : \text { Maximum Brake Torque } \\ O T A M & : \text { Automotive Technologies Research and Developme } \\ & \text { nt Center }\end{array}$

\section{PFI : Port Fuel Injection \\ THC : Total Hydrocarbon}

\section{Conflict of Interest Statement}

The authors declare that there is no conflict of interest in the study.

\section{CRediT Author Statement}

Abdurrahman Demirci: Conceptualization, Supervision, Writing-original draft, Validation,

Hüseyin Emre Doğan: Conceptualization, Writing-original draft, Validation, Data curation,

Ömer Cihan: Data curation, Formal analysis,

Osman Akın Kutlar: Data curation, Formal analysis

\section{References}

[1] Heywood JB. Internal Combustion Engine Fundamentals. United States: McGraw-Hill Education; 2005.

[2] Pulkrabek WW. Engineering Fundamentals of The Internal Combustion Engines. USA: Pearson Prentince Hall; 2004.

[3] Nakao Y, Uchiyama Y, Hisano A, Saitou M, Sobakiri K. Effects of Port Injection Specifications on Air-Fuel Ratio and Emission Behavior under Transient Operation. SAE Tech Pap [Internet]. 2017 [cited 2020 Sep 27];(2017-32-0059).

Available from: https://www.sae.org/publications/technicalpapers/content/2017-32-0059/

[4] Costanzo VS, Heywood JB. Mixture preparation mechanisms in a port fuel injected engine. SAE Tech Pap. 2005;(2005-01-2080).

[5] Balki MK, Çavuş V, Duran İU, Tuna R, Sayin C, Cavus V, et al. Experimental Study and Prediction of Performance and Emission in an SI Engine Using Alternative Fuel with Artificial Neural Network. Int J Automot Eng Technol [Internet]. 2018 Apr 3 [cited 2020 Oct 23];7(1):58-64. Available from: http://ijaet.academicpaper.org

[6] Yontar AA, Doğu Y. Flame Radius Effects on a Sequential Ignition Engine Characteristics. Int J Automot Eng Technol [Internet]. 2018 Apr 3 [cited 2020 Sep 27];7(1):29-37. Available from: http://dergipark.gov.tr/doi/10.18245/ijaet.438044

[7] Yilmaz T. Sıkıştırma ile Ateşlemeli Motorlarda Bilgisayar Destekli Enerji ve Ekserji Analizi Computer Aided Energy and Exergy Analysis in Compression Ignition Engines. Int J Adv Eng Pure Sci. 2019;31(3):201-7.

[8] Kim H, Yoon S, Xie X Bin, Lai MC, Quelhas S, Boyd R, et al. Effects of injection timings and intake port flow control on the in-cylinder wetted fuel footprints during PFI engine startup process. SAE Tech Pap [Internet]. 2005 May 11 [cited 2020 Oct 28];2005-01-20. Available from: https://www.sae.org/publications/technicalpapers/content/2005-01-2082/

[9] Meyer R, Yilmaz E, Heywood JB. Liquid fuel flow in the vicinity of the intake valve of a port-injected SI engine. SAE Tech Pap [Internet]. 1998 Oct 19 [cited 2020 Oct 28];982471. Available from: https://www.sae.org/publications/technical-papers/content/982471/

[10] Zhao FQ, Yoo JH, Lai MC. Spray targeting inside a production-type intake port of a 4-valve gasoline engine. SAE Tech Pap [Internet]. 
1996 Feb 1 [cited 2020 Oct 28];960115. Available from: https://www.sae.org/publications/technical-papers/content/960115/

[11] Nogi T, Ohyama Y, Yamauchi T, Kuroiwa H. Mixture formation of fuel injection systems in gasoline engines. SAE Tech Pap [Internet]. 1988 Feb 1 [cited 2020 Oct 28];880558. Available from: https://www.sae.org/publications/technical-papers/content/880558/

[12] Anand TNC, Ravikrishna R V. Modelling of mixture preparation in a small engine with Port Fuel Injection. Prog Comput Fluid Dyn. 2012;12(6):375-88.

[13] Cardosa TJPL. Port Fuel Injection Strategies for a Lean Burn Gasoline Engine. University of Brighton; 2011.

[14] Zhao FQ, Lai MC, Harrington DL. The Spray Characteristics of Automotive Port Fuel Injection-a Critical Reviews. In: SAE Technical Papers. 1995.

[15] Kato S, Hayashida T, Iida M. The Influence of port fuel injection on combustion stability. Yamaha Mot Tech Rev. 2008;1-11.

[16] Arcoumanis C, Gold MR, Whitelaw JH, Xu HM, Gaade JE, Wallace $S$. Droplet velocity/size and mixture distribution in a singlecylinder four-valve spark-ignition engine. In: SAE Technical Papers. 1998. p. 981186.

[17] Lang KR, Cheng WK. Effects of fuel injection strategy on hc emissions in a port-fuel-injection engine during fast idle. In: SAE Technical Papers. 2006. p. 2006-01-3400.

[18] Hushim MF, Alimin AJ, Mansor MF. Effect of intake manifold angle of port-fuel injection retrofit-kit to the performances of an S.I. engine. In: Applied Mechanics and Materials. 2012.

[19] Kutlar OA. A New method to decrease the fuel comsumption at part load conditions of four stroke ottocycle (rochas) engine (skipperiod engine). Istanbul Technical University; 1999.

[20] Tekeli Ö. Designing and Production Ignition and Injection Units of a Gasoline Engine with Skip Cycle. [İstanbul]: İstanbul Technical University; 2013.

[21] Cheng CO, Cheng WK, Heywood JB, Maroteaux D, Collings N. Intake port phenomena in a spark-ignition engine at part load. SAE Tech Pap [Internet]. 1991 Oct 1 [cited 2020 Oct 28];912401. Available from: https://www.sae.org/publications/technicalpapers/content/912401/

[22] Harrington JA, Shishu RC. A single-cylinder engine study of the effects of fuel type, fuel stoichiometry, and hydrogen-to-carbon ratio on $\mathrm{CO}, \mathrm{NO}$, and $\mathrm{HC}$ exhaust emissions. SAE Tech Pap [Internet]. 1973 Feb 1 [cited 2020 Oct 28];730476. Available from: https://www.sae.org/publications/technical-papers/content/730476/ 